\title{
Determinants of Audit Fee Based on Client Attribute, Auditor Attribute, and Engagement Attribute to Control Risks and Prevent Fraud: A Study on Public Accounting Firms in Sumatra-Indonesia
}

\author{
Tulus Suryanto ${ }^{1}$
}

\begin{abstract}
:
The purpose of this research is to examine the effect of client attribute, auditor attribute, and engagement attribute to audit fees and the effect of audit fees to control risks and fraud prevention. The respondents involved in this research were auditors working in public accounting firms in Bandar Lampung, Palembang and Jambi. Based on the census sampling method, the total sample in this research was 104 respondents from public accounting firms in Bandar Lampung, Palembang and Jambi. In this research, Partial Least Square analysis was employed to test the hypotheses. The results of this research indicate that client attribute, auditor attribute, and engagement attribute are the dominant factors affecting audit fees. The results also show that audit fees have an effect on risk control and fraud prevention.
\end{abstract}

Key Words: client attribute, auditor attribute, engagement attribute, audit fees, control risk, and fraud prevention

\footnotetext{
${ }^{1}$ Faculty of Islamic Economic and Business, The State Islamic Institute of Raden Intan Lampung, Indonesia, tulus@iainradenintan.ac.id
} 


\section{Introduction}

One aspect of professionalism that should be possessed by auditors is the ability to conduct audit works in accordance with auditing standards. This aspect, along with other professionalism aspects, determines audit fees for the work performed by auditors (Fachriyah, 2011). In carrying out their auditing duties, auditors should be guided by auditing standards that have been established by the Indonesian Institute of Accountants (IAPI), the common standards, standards of field work and reporting standards (IAPI, 2007). Common standards are a reflection of personal qualities that should be possessed by auditors. It is required that auditors have technical trainings and adequate expertise in performing audit procedures.

Auditing is the collection and evaluation of evidence about information to determine and report the degree of correspondence between the information and the criteria established. It should be done by people who are competent and independent (Arens, 2012). Auditing should be done based on the auditing standards established by the Indonesian Institute of Certified Public Accountants (IAPI).Furthermore, auditors are required to have sufficient competence, so that they are able to carry out auditing processes in accordance with the established procedures. After conducting auditing processes, auditors will receive fees or remuneration from clients for their professional services. According to Lestari (2013) and Thalassinos and Liapis (2013) there are three determinants of audit fees: the client attribute, auditor attribute, and engagement attribute. Research conducted by Lestari (2013) has indicated that the three factors influence the dominance and non-dominance of audit fees. Obviously, the use of audit services is intended to prevent fraud and to control risks. Pramudji (2009) argues that the development in the field of audit services is in line with the change of paradigm, which will support the prevention of fraud and is able to control risks.

This study was conducted based on Lestari's (2013) research which examined the elements of audit fees based on such factors as client attribute, auditor attribute, and engagementattribute. Other variables were developed in the present study as the impact of the application of assessment factors, such as the correlation of audit fees to risk control and fraud prevention.

\subsection{Problem Formulation}

Based on the background, the questions can be formulated as follows:

a. Are client attribute, auditor attribute, and engagement attribute dominant factors which affect audit fees?

b. Do audit fees affect the risk control and prevention of fraud?

\subsubsection{Theoretical Studies and Formulation Studies and Formulation of Hypotheses}




\section{a. Theoretical studies \\ b. Audit Fee}

Audit fees refer to the amount of fees received by auditors for their professional services based on such factors as the complexity of the services, the level of expertise, and many other factors. Sukrisno Agoes (2012) defines audit fee as "the amount of the charge depends, among others, the risk of the assignment, the complexity of the services provided, the level of expertise required to carry out the services of proficiency level, the cost structure of the firm concerned and other professional considerations".

The cost of external audits (audit fees) refers to the amount of compensation for services performed by external auditors. The compensation for the services is related to the amount of time used to complete the work and the value of services provided to the client or the firm. DeAngelo (1981) states that the amount of cost of external audit, or the audit fee varies greatly. According to Al-Shammari et al. (in Fachriyah, 2011), the cost of external audits can also be interpreted as a function of the amount of work done by auditors or the price per-hour and the level of service required.

Hoitash et al. (2007) found that when auditorsnegotiate with management regarding the tariff fees paid related to their works, it is likely that there will be a clear reciprocal concession which would reduce the quality of the audited statements. Elder (2011) states that audit fee reflect the fair value of the works performed by auditors and particularly their audits.

\subsubsection{Client Attribute, Auditor attribute, Engagement attribute}

\section{a. Client Attribute}

Client attribute refers to factors owned by clients in the audit process. There are several indicators of financial distress of client attribute for instance, the size of the client, the client's complexity, risksof the client and client's profitability. According to David Hay (2006), clients' characteristics are one of determinant of the amount of audit fees. The characteristics include firm size, the complexity of client operations, the risk of default, profitability, turnover and the type of industrial debt owned by the client.

\section{b. Auditor Attribute}

Auditor attribute or the characteristic of the auditor determines the degree of audit. This includes auditors' specialization, time for audit, and location. Furthermore, David Hay (2006) states that the far distance between KAP and the client will make greater cost of audit. 


\section{c. Engagement Attribute}

The third characteristic is the characteristic of assignment, which is a determining factor with regard to the amount of audit fee. This includes the audit assignment, audit problem, the time gap between the date of the balance sheet and the audit report (lag), busy season and the number of reports made.

\subsection{Risk Control}

Risk control is the size determination of auditors and the possibility of mistakes (misstatements) in a segment of the audit that goes beyond the tolerance limits. This is not detected or prevented by the internal control structure of the client. Risk control contains such elements as:

a) The client's internal control structure - whether it is effective enough to detect or prevent errors;

b) The auditor's will to make such determination below the maximum value $(100 \%)$ in the audit plan. For example, the auditor concludes that the internal control structure is ineffective in preventing ordetecting errors.

\subsection{Fraud Prevention}

The Association of Certified Fraud Examiner (1993) defines fraud auditing as "an initial approach (proactive) to detecting financial frauds, using accounting records and information, analytical relationships, and an awareness of fraud perpetration and concealment efforts". Another definition of fraud auditing is an initial approach which is pro-active to detect financial fraud, using records and accounting information, analytical relationships and the nature of prudence for the acts of fraud and attemptsto cover-up of fraud actions (Anonymous 2000). Fraud is also defined as irregularities committed with the intention of doing so.ACFE defines fraud as an intentional act of taking advantages by way of abusing a position/title or stealing assets/resources within organizations (Singleton, 2010).

ACFE classifies fraud into three forms of deviation: financial reporting irregularities, asset miss appropriation, and corruption. Minimizing fraud actions can be done by three things: fraud prevention, fraud detection, and fraud investigation. Generally, fraud on financial reporting statements can be detected through the analysis of financial statement, including vertical and horizontal analyses. Misappropriation of assets can be detected by such methods as analytical reviews, statistical sampling, vendor or outsider complaints, site visit-observations. On the other hand, corruption can be detected fromcomplaints made by coworkers, reports from peers, or suppliers who are not satisfied and submitting a complaint to the company. On suspicion of irregularities, an analysis of the suspect or the transaction is then conducted. The irregularities can be seen from the characteristics (red flag) of the recipient and the giver. Based on the three aspects, Rezaee (2002) identified several attributes of fraud: (1) identify the symptoms and red flags; (2) identification 
of opportunities; (3) assessment symptoms, red flags and opportunities; and (4) reporting.

\subsubsection{Development of Hypothesis a. Client attribute, auditor attribute, and engagement attribute are decisive fee}

According to David Hay (2006), determinants of audit fee consist of three characteristics, namely the characteristics of the client (client attribute), characteristics of auditors (auditor attribute) and the characteristics of the assignment (engagementattribute). Research conducted by Hay (2006) has proven that client attribute, auditor attribute, and engagement attribute are determinants of the audit engagement fee. This research was then followed up by Lestari (2013), who found that the client attribute is a dominant factor in the determination of audit fees, followed by attribute of auditors and audit of engagement. Similar research was conducted by Suhartinas (2014), which proved that the client attribute and auditor attribute can affect the cost of audit. In Indonesia, the amount of audit fees is a factor which determines auditors' judgment for accepting assignments from clients. Determinants of audit fees are crucial factors seen by auditors in determining the fee. Based on the phenomenon occurring in Indonesia and the results of previous research, the hypothesis is formulated as follows:

H1: Client attribute, auditor attribute, and engagement attribute are dominant factors affecting the audit fee

\section{b. Audit fee affects the risk control and prevention of fraud}

According to Purnamasari (2013), audit risk is one important factor which determines the amount of audit fee. A unit risk is the risk arising from auditors who unconsciously modify their opinions; accordingly, financial statements contain misstatements (PSA No. 25). Risk control has a direct relationship with the audit fee. Based on research on factors that affect audit fee (Simunic, 1980; Francis \& Simon, 1987; Chan et al., 1993; Gerrard et al., 1994; Firth, 1997; Craswell \& Francis, 1999; Carey et al., 2000; Ferguson et al., 2003; Casterella et al., 2004; the Decree of the Chairman of the IAPI Number: KEP.0024 / IAPI / VII / 2008), it can be seen that the level of audit risk that includes risk control affects the amount of audit fees. The greater the risk audits that include risk control, the greater the audit fee to be received by the auditor.

Fraud refers to irregularities and errors.One of possible efforts to reduce fraud is by awarding employees who have contributed to the detection of fraudulent behavior and enforced anti-fraud culture (Singleton, 2010). The award could be in the form of promotion or fee. Research conducted by Yuniarti (2010) indicates that the form of respect for employees taking into account the amount of fee relates positively to the prevention of fraud. Based on the above explanation, the hypothesis is formulated as follows: 
H2: Client attribute, auditor attribute, and engagement attribute affect the risk control and prevention of fraud.

\section{Research Methodology}

\subsection{Population and Sample}

Population refers to a whole group of people, events, or things of interest that researchers investigate (have now, 2006). The study population was all auditors who worked at several Public Accounting Firms (KAP) in the Sumatra region including the city of Bandar Lampung, Palembang and Jambi. They were listed in the directory KAP 2012-2013.

\subsection{Data Collection Technique}

Census sampling technique was employed in this study to gather the data. It was done by taking all existing sample to be studied.

\subsection{Analysis Techniques}

\subsubsection{Data quality test}

Data quality test was conducted to evaluate the reliability and validity using SPSS version 18.0 (Statistical Product and Service Solution). The test was intended to measure the reliability of the questionnaire, which is an indicator of the variables or constructs. The reliability measurement was performed with a Cronbach Alpha test. A construct is said to be reliable if the value of Cronbach Alpha is $\geq 0.60$ (Nunnaly, 1967; Ghozali 2004).

Furthermore, the validity test was used to measure whether or not the questionnaire is legitimate or valid. A questionnaire is said to be valid if the questions in the questionnaire are capable of expressing responses that will be measured by the questionnaire.

The validity test was done by bivariate correlation between each score of total indicator constructs. If the total correlation constructs show significant results, each question is a valid indicator.

\subsubsection{Hypothesis Testing}

In this study, the analysis of data used the approach of Partial Least Square (PLS) and SmartPLS software.PLS is a structural equation modeling (SEM) based on components or variants. According to Ghozali (2006), PLS is an alternative approach that shifts the covariance-based SEM approach to one based on general 
covariance.SEM is based on test causality/PLS whereas theory is more predictive models.

PLS is a powerful method of analysis (Wold, 1985 in Ghozali, 2006) because it is not based on many assumptions. For example, the data should be normally distributed and the sample should not be large. In addition, it can be used to confirm the theory. PLS can also be used to explain the relationship between latent variables. Furthermore, PLS can simultaneously analyze the constructs formed by the reflexive and formative indicators. This cannot be done by SEM-based covariance because it would be unidentified models.

\section{Results and Discussion}

\subsection{Descriptive Statistics}

\subsubsection{Delivery and Returns of the Questionnaire}

The respondents involved in this study were public accountantsworking in the city of Bandar Lampung, Palembang and Jambi. The researchers chose the respondents who met the above criteria. Data collection was performed 2 months. The dissemination of the research questionnaire was conducted directly or indirectly (through an intermediary). The numbers of questionnaires that can be processed were as many as 104 pieces.

Table 1. Characteristics of Respondents

\begin{tabular}{|l|l|l|}
\hline \multicolumn{1}{|c|}{ Description } & \multicolumn{1}{|c|}{ Amount } & \multicolumn{1}{c|}{ Percentage } \\
\hline Gender & & \\
Male & 63 & $60,57 \%$ \\
Female & 41 & $39,42 \%$ \\
\hline 2. Age & 3 & $2,88 \%$ \\
>21 Year & 73 & $70,19 \%$ \\
21-25 Year & 12 & $11,53 \%$ \\
26-30 Year & 9 & $8,65 \%$ \\
31-35 Year & - & $0 \%$ \\
36-40 Year & 5 & $4,80 \%$ \\
41-45 Year & - & $0 \%$ \\
46-50 Year & 2 & $1,92 \%$ \\
$>50$ Year & & \\
\hline 3. Position the last & 4 & $3,84 \%$ \\
Partner & 5 & $4,80 \%$ \\
Manajer & 20 & $19,23 \%$ \\
Senior Auditor & 75 & $72,11 \%$ \\
Junior Auditor & \multicolumn{2}{|l}{} \\
\hline
\end{tabular}




\begin{tabular}{|l|l|l|}
\hline 4. Last Education & & \\
D3 & 30 & $28,84 \%$ \\
S1 & 68 & $65,38 \%$ \\
S2 & 6 & $5,76 \%$ \\
S3 & 0 & $0 \%$ \\
& & \\
\hline \multicolumn{1}{|c|}{ Description } & Amount & \multicolumn{1}{|c|}{ Percentage } \\
\hline 5. Long working & & \\
& & \\
< 5 th & 77 & $74,03 \%$ \\
5-10 year & 15 & $14,42 \%$ \\
11-16 year & 7 & $6,73 \%$ \\
17-22 year & 1 & $0,96 \%$ \\
$>22$ year & 4 & $3,84 \%$ \\
\hline
\end{tabular}

Source: primary data processed

\subsubsection{Data Quality Assessment}

The test of the quality of the data includes reliability and validity tests. The reliability test was conducted with Cronbach alpha test using SPSS. A construct is said to be reliable if the value of Cronbach alpha is > 0.60 (Nunnaly, 1967; Imam, 2004). The results indicate that the data are reliable and valid. The following is the recapitulation of the reliability test results, presented in Table 2, 3 and 4.

Table 2. The Reliability Test Results

\begin{tabular}{|c|l|c|c|}
\hline No & \multicolumn{1}{|c|}{ Variable } & Value ofCronbach Alpha & Result \\
\hline 1 & Client attribute & 0.82 & Reliabel \\
\hline 2 & Auditor attribut & 0.67 & Reliabel \\
\hline 3 & Enggament attribute & 0.77 & Reliabel \\
\hline 4 & Audit fee & 0.87 & Reliabel \\
\hline 5. & Control risk & 0.66 & Reliabel \\
\hline 6. & Prevention of fraud & 0.78 & Reliabel \\
\hline
\end{tabular}

Source: Primary data processed

Table 3. Validity of Test Results

\begin{tabular}{|c|l|c|c|c|}
\hline No & \multicolumn{1}{|c|}{ Variable } & $\begin{array}{c}\text { Range of } \\
\text { correlation }\end{array}$ & Significance & Results \\
\hline 1 & Client attribute & $0.616^{* *}-0.756^{* *}$ & 0.01 & Valid \\
\hline 2 & Auditor attribut & $0.728^{* *}-0.791^{* *}$ & 0.01 & Valid \\
\hline 3 & Enggament attribute & $0.773^{*} *_{-}-0.780^{* *}$ & 0.01 & Valid \\
\hline 4 & Audit fee & $0.791 *_{-}-0.822^{* *}$ & 0.01 & Valid \\
\hline
\end{tabular}




\begin{tabular}{|l|l|l|l|l|}
\hline 5. & Control risk & $0.693 * *-0.754 * *$ & 0.01 & Valid \\
\hline 6. & Prevention of fraud & $0.734 * *-0.812 * *$ & 0.01 & Valid \\
\hline
\end{tabular}

Source: Primary data processed

\subsubsection{Testing Structural Model (Inner Model)}

The testing of the inner structural model or models aims to look at the relationship between the constructs, the significant value and R-square. The structural models were evaluated using the R-square for the dependent construct, Stone-Geisser Qsquare test for predictive relevance, and the $t$ test and significance of the coefficient parameters of structural lines.

In assessing the models with PLS, the R-square for every dependent latent variable was seen. Changes in the value of R-square can be used to assess the effect of certain independent latent variables on the dependent latent variable. The following table is an R-square estimation results by using SmartPLS.

Table 4. R-square value

\begin{tabular}{cc}
\hline Variable & R-Square \\
\hline Audit fee & - \\
Auditor attribut & 0,064 \\
Enggament attribute & 0,185 \\
Client attribute & 0,616 \\
Control risk & 0,346 \\
Fraud prevention & 0,671 \\
\hline
\end{tabular}

Source: Output SmartPLS

\subsubsection{Hypothesis Testing}

To test the hypothesis, we can see the value of t-statistics. The limit to reject and accept the proposed hypothesis is \pm 1.96.If the value of $t$ is in the range of 1.96 and 1.96 , the hypothesis will be rejected.I In other words, the null hypothesis (H0) is accepted. The estimation results of the t-statistic can be seen on the result for the inner weight (Table 5). 
Table 5. Result for inner weights

\begin{tabular}{ccccc}
\hline Variable & $\begin{array}{c}\text { Original } \\
\text { Sample } \\
\text { Estimate }\end{array}$ & $\begin{array}{c}\text { Standard } \\
\text { Deviation }\end{array}$ & T-Statistic & Hypothesis \\
\hline CA -> AF & 0,139 & 0,083 & 4,851 & Accepted \\
AA-> AF & 0,522 & 0,022 & 6,563 & Accepted \\
EA -> AF & 0,339 & 0,013 & 7,345 & Accepted \\
AF -> CR & 0,137 & 0,007 & 4,277 & Accepted \\
AF -> PP & 0,185 & 0,081 & 2,282 & Accepted \\
\hline
\end{tabular}

Source: Output SmartPLS

\subsubsection{Discussion}

\section{Hypothesis 1}

The first hypothesis (H1) is that the client attribute, auditor attribute, and engagement attribute are dominant factors affecting the audit fee.

The test results of the audit fee coefficient between the parameters of the client attribute indicate that there is a positive effect of 0,139 , with a value of t-statistic of 4.851 and significant at 0.05 . The variable of auditor attribute to audit fees showed a positive value of t-statistic 0.522 with 6.563 , while the variable of engagement attribute to the audit showed no positive effect 0.339 , with a value of t-statistic for 7.43 and significance at 0.05 . The t-statistic value was far above the critical value \pm 1.96. Therefore, the first hypothesis can be accepted.

The results support the research of David Hay (2006), Gamal (2012), and Lestari (2013) which proved that client attribute, auditor attribute, and engagement attribute are dominant factors affecting the audit fee. These results also suggestthat the amount of audit fees in Indonesia is a factor which determines auditors' judgment in accepting assignments from clients. Determinants of audit fees are crucial factors seen by auditors in determining the fee.

\section{Hypothesis 2}

The second hypothesis (H2) deals with the effect of the audit fee to risk control risk and fraud prevention.

The test results of the audit fee coefficient between the parameter to control risk showed no positive effect of 0.137 , with a t-statistic of 4.227 and significance at 0.005 . For the variable audit fee to preventive audit showed positive value of $t$ statistic 0.185 to 2.282 , t-statistic value that is far below the critical value \pm 1.96 . Therefore, the secondhypothesis can be accepted. 
Audit fee is proven to have an effect on risk control.This research supports the research carried out by Purnamasari (2013) which proved that the audit risk is one important factor in determining the amount of audit fees by KAP.

Audit risk becomes one of considerations of auditors in performing audits, because it is related to the amount of time that will be used in the audit process. Therefore, it will affect the amount of fee to be received or determined. In other words, compensation for services is related to the amount of time used to complete the work and the value of services provided to the client or the firm. The results also support the view of De Angelo (1981), who states that the audit fee income is highly variable magnitude. It can be affected various factors, including audit risk.

The results also show that audit fee has an effect on prevention audit. These results support the results of research conducted by Yuniarti (2010) which provide evidence that the amount of fee relates positively to the prevention of fraud; this becomes a form of respect from employers. The phenomenon in Indonesia regarding the amount of the fee greatly affects the performance of auditors.A proper amount of fee is provento have a positive effect on the prevention of fraud.

\section{Conclusion and Discussion}

The results showed that:

\subsection{Client attribute, auditor attribute, and engagement attribute are dominant factors affecting the audit fee.}

The results of this study support the research of David Hay (2006), Suhartinar (2014) and Lestari (2013) which proved that client attribute, auditor attribute, and engagement attribute are dominant factors affecting the audit fee. These results also prove that the amount of audit fees in Indonesia is a factor determining auditors' judgment in accepting assignments from clients. The determinants of audit fees are crucial factors seen by auditors in determining the fee.

\subsection{Audit fee to affect the risk control and Prevention of fraud.}

This research supports the research carried out by Purnamasari (2013) which proved that the audit risk is one important factor in determining the amount of audit fees by KAP. Audit risk becomes one of considerations of auditors in performing the audit, because it is related to the amount of time that will be used in the audit process. Therefore, it will affect the amount of fee to be received. The results also show that audit fee has an effect on the prevention audit. These results support the results of research conducted by Yuniarti (2010) which showed that the amount of fee relates positively to the prevention of fraud. The phenomenon in Indonesia regarding the amount of the fee greatly affects the performance of an auditor. A proper amount of fee is proven to have a positive effect on the prevention of fraud. 


\section{References}

Agoes, Sukrisno. 2004. Auditing (Accountants Examination) by Public Accounting Firm. Volume I. Third Edition. Jakarta: Issuing Faculty of Economics, University of Indonesia.

Al-Shammari, B., Abdullah Al-Yaqout, and Ahmad al-Husaini. 2008. Determinants of audit fees in Kuwait. Journal of the Academy of Business and Economics.Vol 8 (1).

Arens, A.A and J. K. Loebbecke. 2012. Auditing: An Integrated Approach. Fourth Edition.EnglewoodCliffs_New Jersey. Prentice-Hall International, Inc.

Boynten, WC, Johnson, RN and Kell, WG 2001.Modern Auditing.7th edition. New York: John Wiley \& Sons, Inc.

DeAngelo, LE (1981). "Size and Auditor Quality Auditor" .Journal of Accounting and Economics, Dec, Vol.3, No.3: 183-199.

Fachriyah, N. 2011.Faktor Factors Influencing Audit Fee Determination by a public accounting firm in Malang. Thesis. Malang. Brawijaya University.

Hay, David and David Davis. 2006. The Voluntary choise of An Audit of Any Level of Quality.Auditing: A Journal of Practice and Theory, Vol.23, No.2.

Hoitash, R. and U. Hoitash. 2007. The Role of Audit Committees in Managing Relationship with External Auditors After SOX: Evidence from US American Accounting Association Annual Meeting and Accounting Research Workshops Bentley College and Suffolk University.

Indriantoro, B. and B. Supomo.2003.Research Methodology business accounting and management. BPFE. Yogyakarta.

Indonesian Institute of Certified Public Accountants. 2007. Generally Accepted Accounting Standards. Salemba, Jakarta.

Indonesian Institute of Certified Public Accountants.Compartment Public Accountant. 2009. Public Accounting Firm Directory. Jakarta.

Jogiyanto, \&Abdillah, W. (2009) .Consep and PLS Applications For Research Empiris. Yogyakarta: BPFE.

Jusup, Al. Haryono. 2001. Auditing (Auditing) Volume 1. Yogyakarta: STIEYKPN.

Keane, Matthew J., Randal J. Elder and Susan M. Albring, "The effect of the type and number of internal control weaknesses and their remediation on audit fees", Review of Accounting and Finance, Vol. 11, No. 4, pp. 377- 399, 2008.

Indonesian Institute of Accountants Decision No. 024 / IAPI / VII / 2008 on Policy Determination of Audit Fee. Dated July 2, 2008.

Lestari, V. 2013.The evidence on the impact of internal controls and good corporate governance to the audit fee.Thesis. Jakarta. Syarif Hidayatullah State Islamic University.

Pradika, NA 2009. Influence of the Audit Risk Audit fee. Skripsi. Surabaya. Airlangga University.

Pramudji, Arum.,AgusPurwanto. Effect of Profitability, Leverage, Ownership Structure and Status of the Company's Financial Statements in Manufacturing 
Company in Indonesia.Diponegoro Journal of Accounting, Volume 1, Number 1, Hal.1-10, 2009.

Purnamasari, Dessy. 2013. Effect of audit risk (inherent risk, control risk detection riskdan) the determination of the audit. FEB UB.

Have now, U. 2007. Research Methods For Business. Men Kwan Yon (translators) Metodologi Peneliitian to Bisniss.Edition 4. Four Salemba, Jakarta.

Singleton and Singleton. 2010. Fraud Auditing and Forensic Accounting.Fourth Edition Wiley Corporate F \& A.

Suhartinar, Tiara.N., (2014). Convergence influence IRFS and client attribute to audit costing exsternal.Skripsi. Diponegoro University.

Thalassinos, E., \& Liapis, K. (2013). A Comparative Analysis for the Accounting Reporting of Employee Benefits between IFRS and other Accounting Standards: A Case Study for the Biggest Listed Entities in Greece. International Journal of Economics and Business Administration, 1(1), 99-124. 